\title{
SURVEY LIBRARY
}

Pennsylvanian Tree Fern Compressions

Caulopteris, Megaphyton, and Artisophyton gen. nov. in Illinois

Hermann W. Pfefferkorn

ILLINOIS STATE GEOLOGICAL SURVEY Jack A. Simon, Chief Urbana, IL 61801 
Digitized by the Internet Archive in 2012 with funding from

University of Illinois Urbana-Champaign

http://archive.org/details/pennsylvaniantre492pfef 


\title{
Pennsylvanian Tree Fern Compressions \\ Caulopteris, Megaphyton, and \\ Artisophyton gen. nov. in Illinois
}

\author{
Hermann W. Pfefferkorn*
}

\begin{abstract}
Compression-impression fossils of tree fern stems often exhibit the configuration of the vascular bundle of the leaf petiole. The shape of the trace is one of the major criteria used to distinguish higher taxa (genera or even families) among the tree ferns. Thus compression-impression fossils can yield information on the natural classification of these stems.

Two distinct configurations of the vascular bundle are known from tree fern stems of Pennsylvanian and Mississippian age. One is a sequence of shapes from horseshoe-shape to a closed oval containing one internal trace. This sequence occurs on stems with four or more rows of leaf scars in the genus Caulopteris Lindley and Hutton, 1832. It is also found in stems with only two rows of leaf scars in the mature stem; these stems are called Megaphyton Artis, 1825.

The other configuration of the vascular bundle is a sequence of shapes from a closed rectangular external trace having a deeply indented abaxial side and one internal trace to a stage in which two external traces, each containing one internal trace, have formed. An intermediate stage of the sequence is an external rectangular trace, also indented, with two internal traces. This sequence is found only on stems with two rows of leaf scars. To separate this sequence from Megaphyton, which also has two rows, a new genus, Artisophyton, is proposed in this paper.

Size, form, and arrangement of the leaf scars are so varied that it is uncertain whether natural species can be established within these three genera. It is suggested here that the height to width ratio in relation to the size is adequate to delineate form-species. In Illinois several form-species of Caulopteris, one formspecies of Megaphyton, and two form-species of Artisophyton are known.
\end{abstract}

*Present address: Department of Geology, University of Pennsylvania, Philadelphia, PA 19174. 


\section{INTRODUCTION}

The study of compression-impression fossils of stems of tree ferns in Illinois provides new information that helps to differentiate taxa. The genera can be more easily delineated than the species, which show a great variability in their characters.

In the literature of tree ferns in Illinois, only petrifactions have been systematically treated (Gillette, 1937; Morgan, 1959; Stidd, 1971). The compression-impression species were illustrated in general compression flora studies (Lesquereux, 1866, 1870, 1879-1884; Janssen, 1957; Langford, 1958, 1963). The most recent report on the stems of Paleozoic tree ferns in general was given by Andrews and Doubinger (in Boureau, 1970).

\section{Materials}

The specimens described in this study are, with a few exceptions, from the same shales that have yielded large numbers of other compressionimpression fossils. Their positions in the stratigraphic section are shown in text figure 1, their localities in text figure 2.

The "Lower Chesterian" (text fig. 1) would be approximately equivalent to the uppermost Viséan in European time-stratigraphy. The beds of Pennsylvanian age that have yielded stems are most probably equivalent to the upper part of the Westphalian and the lower part of the Stephanian.

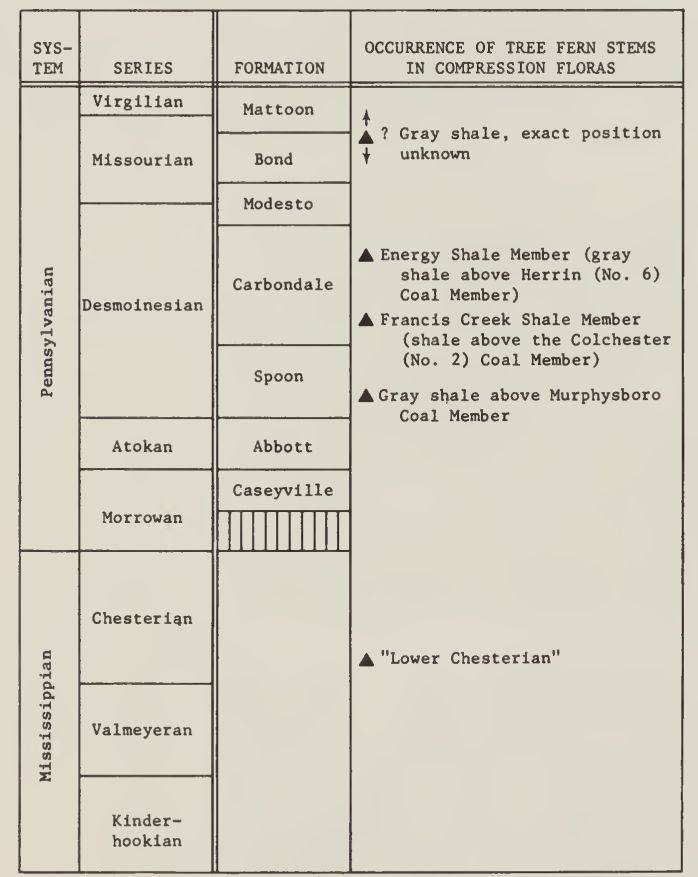

Text fig. 1 - Occurrence of tree fern stems in compression floras in Illinois.
In the descriptions of specimens from some of the collections used, localities are not precise. In some, only the name of a nearby town or mine is given. However, in all cases there was enough information to assign at least an approximate stratigraphic position.

In Illinois tree fern stems are preserved both as petrifactions and as compression-impression fossils. The compression-impression fossils have been found in Illinois in four modes of preservation:

1) Compression of stem as a thin film of coal in shale.

2) Impression without carbonaceous film in ironstone nodules in gray shale. Normally there is only one leaf scar per nodule. 
3) Cast consisting of ironstone in gray shale. Traces of vascular bundle are present, but cell structure is not preserved.

4) Cast in sandstone. No internal features are preserved.

Prefix designations of specimen numbers indicate the source collection and present location of material studied:

ISGS - Illinois State Geological Survey, Urbana, Illinois

ISM - Illinois State Museum, Springfield, Illinois

PP, UP, or UC - Field Museum of Natural History, Chicago, Illinois

USNM - United States Nationa1 Museum, Washington, D.C.

Harvard - Department of Biology, Harvard University, Cambridge, Massachusetts

Acknowledgments

I wish to express my gratitude to $\mathrm{Mr}$. R. L. Leary, Curator, Illinois State Museum, Springfield, and Dr. E. S. Richardson, Curator, Field Museum of Natural History, Chicago, for their hospitality while I studied specimens in their museums. Most helpful were discussions of living tree ferns with Professor Rolla Tryon, Dr. Alice F. Tryon, and their students at Harvard University. Professor Tom L. Phillips, University of Illinois, introduced me to the study of structurally preserved tree ferns and thus influenced my interest in the tree ferns. I thank Professor Tom L. Phillips, Professor Rolla Tryon, and Dr. Benton $\mathrm{N}$. Stidd, Western Illinois University, for critically reading this manuscript and making helpful suggestions; their cooperation does not imply that they agree with all of my conclusions.

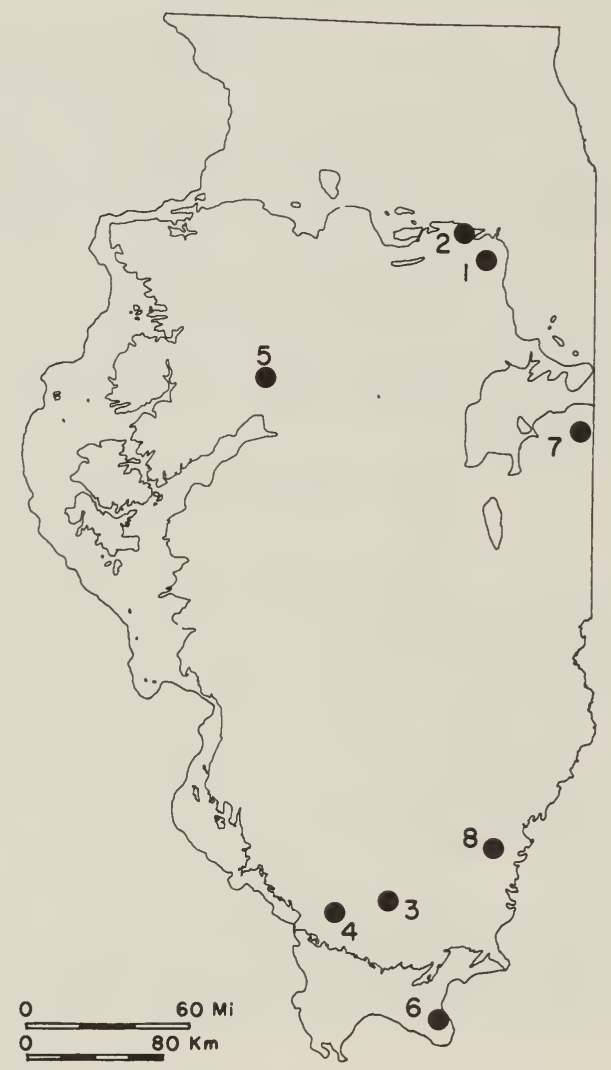

Text fig. 2 - Localities at which stems of tree ferns have been found in Illinois (1 - Braidwood; 2 - Morris; 3 - Herrin; 4 - Murphysboro; 5 - Peoria; 6 - Bay City; 7 - Westville; 8 - Carmi). Limits of the Pennsylvanian System in Illinois are shown. 
TAXONOMY

Megaphyton Artis, 1825

\section{Synonym: Zippea Corda, 1845}

Emended diagnosis.-Stem of tree fern (compression or impresion); leaf scars in two vertical rows on opposite sides of the stem; leaf scars oval to rectangularly oval; trace of vascular bundle with stewartiopteroid or stipitopteroid configuration.

Discussion.-Specimens of Megaphyton can be distinguished from those of Caulopteris only if at least half of the stem's outer surface is preserved. If there is only one row of leaf scars without adjacent tissue, the specimen may belong to either genus.

Megaphyton protuberans Lesquereux, 1866

Text fig. 3, A; p1. 5, fig. 1

Basionym: Megaphytum protuberans Lesquereux, L., 1866, Report on the fossil plants of Illinois, in: Worthen, A. H., 1866, Palaeontology: Geological Survey of Illinois, v. 2, p. 458, p1. 47, figs. 1-2.

Holotype: ISM 1632 .

Occurrence: Silty, yellowish sandstone, Bay City, Pope County, I11inois.

Age: Chesterian (probably early).

The specimen was figured first by Lesquereux and later by Janssen; in both figures the specimen was upside down, probably because the lower third of the leaf scar protrudes steeply outward and the boundary of the leaf scar is most clearly visible there. Therefore, the lower third was considered the distal end of the leaf scar. However, assuming that the vascular bundle was open towards the adaxial side, the correct position of the specimen would be that shown in the figures of this paper.

The specimen is $65 \mathrm{~cm}$ long, has a diameter of more than $10 \mathrm{~cm}$, and displays nine leaf scars. The scars are badly preserved, but a few show a horseshoe-shaped vascular bundle that occupies only the lower third of the leaf scar. Measurements:

\begin{tabular}{|c|c|c|c|}
\hline \multirow{3}{*}{ Leaf scar: } & Height & Width & $\underline{\mathrm{H}: W}$ \\
\hline & $75 \mathrm{~mm}$ & $50 \mathrm{~mm}$ & 1.36 \\
\hline & $65 \mathrm{~mm}$ & $55 \mathrm{~mm}$ & 1.18 \\
\hline Vascular bundle: & $21 \mathrm{~mm}$ & $26 \mathrm{~mm}$ & 0.8 \\
\hline
\end{tabular}

The leaf scars are $5 \mathrm{~mm}$ apart vertically. 
Langford (1958, fig. 241) figured a specimen having a row of leaf scars from the Francis Creek Shale Member at Wilmington (text fig. 3, B) that had been figured before by Noé (1925, p1. 45, fig. 5) and Janssen (1957, fig. 88). Langford designated this specimen (UP 423 = UC 40001) Megaphyton braidwoodense, which is a nomen nudum. It is not clear whether the specimen belongs to Megaphyton or Caulopteris.

Text fig. 3 - Species of Megaphyton and Artisophyton from Illinois. A - M. protuberans; B - Specimen UP $423=$ UC 40001 from the Francis Creek Shale; C - A. insignis; D - A. mclayi.

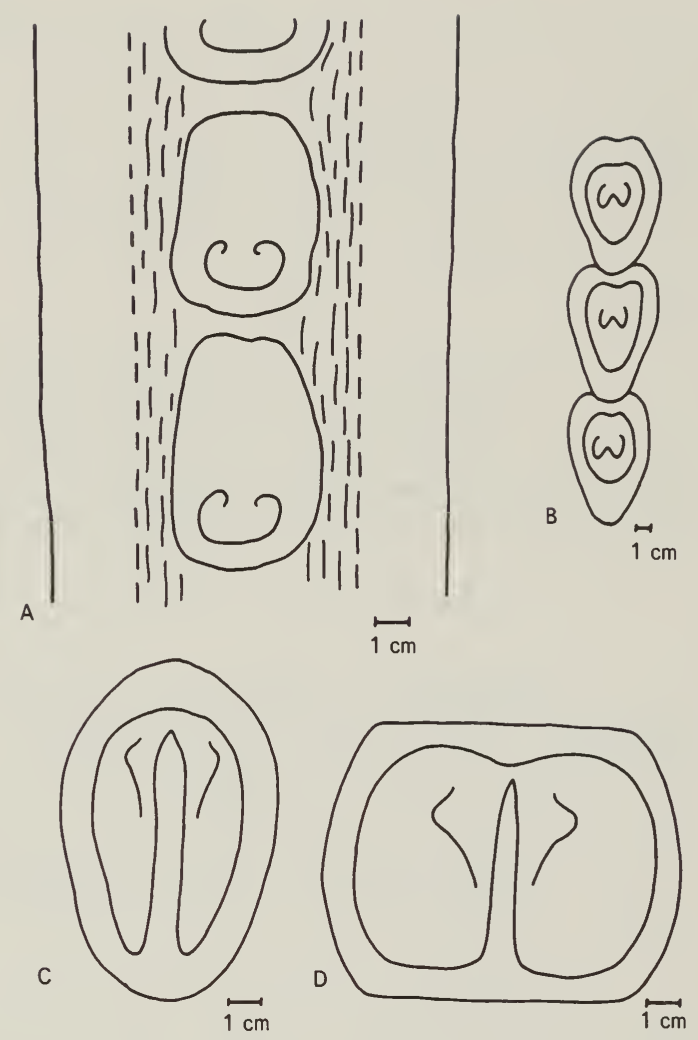

Artisophyton gen. nov.

Diagnosis.-Stem of tree fern (compression or impression); leaf scars in two vertical rows on opposite sides of the stem; leaf scars round or rounded rectangular; leaf scars often in continuous rows; outer trace of vascular bundle closed, with deep indentation on the lower (abaxial) side; some leaf scars may show a final stage in which the outer trace is divided into two separate closed traces; inner trace developed from a straight line into two S-shaped traces (text fig. 4).

Derivation of name.-Artisophyton is a combination of the surname of E. T. Artis, who recognized in 1825 that Megaphyton had much in common with living tropical tree ferns, and the Greek word for plant (phyton). 1834) comb. nov.

Type species: Artisophyton approximatum (Lindley and Hutton,

Basionym of type species: Megaphyton approximatum Lindley, John, and William Hutton, 1833-35, Fossil flora of Great Britain or figures 


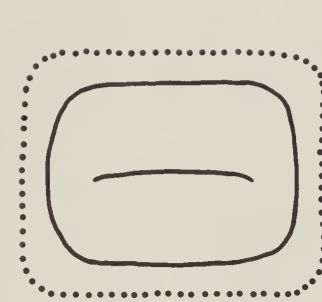

A

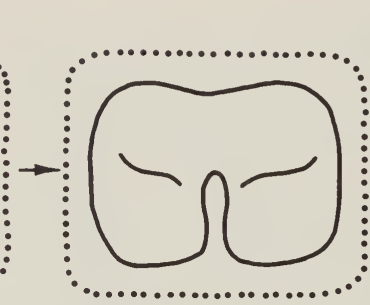

B

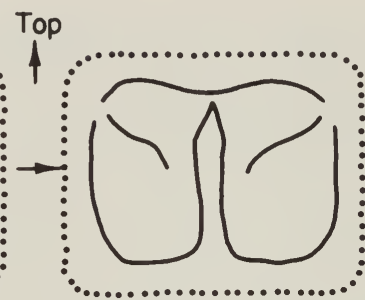

C

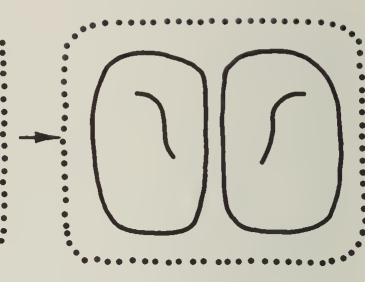

D

Text fig. 4 - Configuration of vascular bundle in leaf scars of Artisophyton and the supposed developmental sequence of the leaf scars in the basal part of the rachis. (A is proximal.)

and descriptions of the vegetable remains found in a fossil state in this country: London, James Ridgway, v. 2, p1. 116.

Artisophyton goldenbergii (Weiss, 1860) comb. nov.

Basionym: Megaphytum goldenbergii Weiss, E., 1860, Ueber ein Megaphytum der Steinkohlen-Formation von Saarbrücken: Zeitschrift der deutschen geologischen Gesellschaft, v. 12, figure on p. 510.

Artisophyton insigniș (Lesquereux, 1866) comb. nov.

Text fig. 3, C; p1. 5, fig. 2; pl. 6, figs. 2 and 3

Basionym: Caulopteris insignis Lesquereux, L., 1866, An enumeration of the fossil plants found in the coal measures of Illinois, with description of the new species, pl. 49, fig. 1, p. 459; in: Worthen, A. H., 1866, Palaeontology: Geological Survey of Illinois, v. 2.

\section{Partial synonymy:}

1866 Caulopteris insignis Lesquereux

1890 Megaphyton insignis Grand'Eury

1940 Megaphyton insignis Janssen, p1. 21

1958 Megaphyton insignis Langford, p. 135, fig. 240

1970 Caulopteris sp., Darrah, p1. 68, fig. 1

(For a more complete pre-1940 synonymy, see Janssen, 1940.)

\section{Holotype: ISM 1720}

Specimens: ISGS PB-3299, ISM 14555, ISM 15290, ISM 15740, PP 730, PP 2936 (? 2583), Harvard 7720 (= S 63)

Occurrences: Energy Shale Member (shale above Herrin (No.6) Coal Member), Carbondale Formation; Francis Creek Shale Member (shale above Colchester (No. 2) Coal Member), Carbondale Formation; ? shale above Murphysboro Coal Member, Spoon Formation. 
Artisophyton malayi (Lesquereux, 1866) comb. nov.

Text fig. 3, D; p1. 4; p1.6, fig. 1

Basionym: Megaphytum MCLayi Lesquereux, L., 1866, Report on the fossil plants of Illinois, p1. 48, p. 458; in: Worthen, A. H., 1866, Palaeontology: Geological Survey of Illinois, v. 2 .

\section{Holotype: ISM 1782}

Specimens: ISGS PB-1298, ISM 1619, PP 726, PP 2259

Occurrences: Energy Shale Member (shale above Herrin (No. 6) Coal Member), Carbondale Formation; Francis Creek Shale Member (shale above Colchester (No. 2) Coal Member), Carbondale Formation; ? shale above Murphysboro Coal Member, Spoon Formation.

\section{Discussion}

Artisophyton approximatum has been chosen as the type species because it is the first published species having the configuration of the vascular bundle as described in the diagnosis of the genus.

In Illinois only two species of this genus have been reported, $A$. mclayi and $A$. insignis. The two species differ in the height to width ratios of their leaf scars (tables 1 and 2; text fig. 5). The scars of $A$. mclayi are wider than they are high, while those of $A$. insignis are higher than wide. Both species were $20 \mathrm{~cm}$ or more in diameter.

Artisophyton mclayi was considered a synonym of $A$. approximatum by Janssen (1940, p. 74), who used height to width ratio as a characteristic. A. approximatum (Lindley and Hutton, 1834), A. goldenbergii (Weiss, 1860), and $A$. mclayi (Lesquereux, 1866) are very similar in height to width ratio. However, Crookal1 (1955, p. 75) pointed out that there are differences in shape and in size. The scars of $A$. approximatum apparently do not touch each other, and they are less angular than those

TABLE 1 - MEASUREMENTS OF SPECIMENS OF ARTISOPHYTON INSIGNIS FROM ILLINOIS ( $\mathrm{H}: \mathrm{W}=$ height to width ratio)

\begin{tabular}{|rrr|crr|}
\hline \multicolumn{3}{|c|}{ Leaf scar } & & \multicolumn{3}{c|}{ Outer vascular bundle } \\
\hline $\begin{array}{c}\text { Height } \\
(\mathrm{mm})\end{array}$ & $\begin{array}{r}\text { Width } \\
(\mathrm{mm})\end{array}$ & $\mathrm{H}: \mathrm{W}$ & $\begin{array}{c}\text { Height } \\
(\mathrm{mm})\end{array}$ & $\begin{array}{c}\text { Width } \\
(\mathrm{mm})\end{array}$ & $\mathrm{H}: \mathrm{W}$ \\
\hline 150 & 110 & 1.36 & 92 & 80 & 1.14 \\
140 & 110 & 1.27 & 90 & 68 & 1.32 \\
135 & 110 & 1.22 & 83 & 78 & 1.06 \\
130 & 100 & 1.30 & 80 & 74 & 1.08 \\
125 & 90 & 1.39 & 80 & 65 & 1.23 \\
- & - & 1.19 & 60 & 55 & 1.09 \\
68 & 57 & 1.15 & 50 & 40 & 1.25 \\
90 & 78 & 1.15 & 60 & 55 & 1.09 \\
\hline
\end{tabular}


TABLE 2 - MEASUREMENTS OF SPECIMENS OF ARTISOPHYTON MCLAYI FROM ILLINOIS ( $\mathrm{H}: \mathrm{W}=$ height to width ratio)

\begin{tabular}{|rcc|crc|}
\hline \multicolumn{3}{|c|}{ Leaf scar } & \multicolumn{3}{c|}{ Outer vascular bundle } \\
\hline $\begin{array}{c}\text { Height } \\
(\mathrm{mm})\end{array}$ & $\begin{array}{c}\text { Width } \\
(\mathrm{mm})\end{array}$ & $\mathrm{H}: \mathrm{W}$ & $\begin{array}{c}\text { Height } \\
(\mathrm{mm})\end{array}$ & $\begin{array}{c}\text { Width } \\
(\mathrm{mm})\end{array}$ & $\mathrm{H}: \mathrm{W}$ \\
\hline 110 & 130 & 0.85 & 75 & 102 & 0.73 \\
110 & 135 & 0.82 & 75 & 108 & 0.69 \\
90 & 120 & 0.75 & 70 & 96 & 0.73 \\
85 & 118 & 0.71 & 80 & 95 & 0.84 \\
- & - & - & 70 & 100 & 0.70 \\
80 & 110 & 0.73 & 52 & 87 & 0.59 \\
80 & 100 & 0.80 & 50 & 75 & 0.66 \\
85 & 94 & 0.90 & 52 & 68 & 0.75 \\
80 & 80 & 1.00 & 55 & 67 & 0.82 \\
\hline
\end{tabular}

of $A$. mclayi and $A$. goldenbergii, which are similar to each other in outline. $A$. approximatum has the smallest leaf scars of the three, and $A$. mclayi the largest. Synonymy should not be established until European species have been revised.

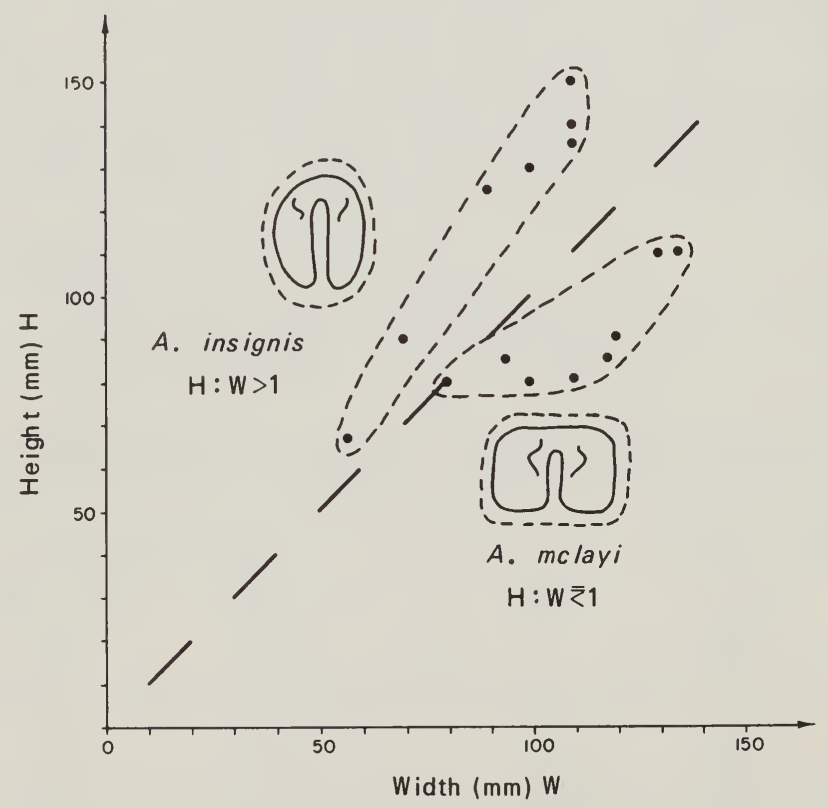

Text fig. 5 - Height to width plot of Artisophyton specimens from Illinois. Dashed line represents a height to width ratio of $1: 1$. 


\section{Caulopteris Lindley and Hutton, 1832}

Description.-Stem of tree fern (compression or impression);

leaf scars in more than two vertical rows, forming either diagonal rows or whorls; leaf scars round or oval, entirely isolated, or connected in vertical direction with the next scar, or covering the whole stem; trace of vascular tissue with stewartiopteroid or stipitopteroid configuration.

\section{Caulopteris sp. A to D}

It will be shown in the discussion section that there is no sound basis for delineating natural species within this genus. In this paper an artificial and preliminary separation of form-species based on differences in height and in height-width ratio was made (text fig. 6 ). The cutoff points are 1.3, 1.9, and 2.6 for the height-width ratio and $100 \mathrm{~mm}$ for the height. The different form-species were designated by letters from A to D. Measurements of specimens assigned to Caulopteris species A through D are given in table 3; and these species are illustrated on text figure 7. A few specimens show additional features and are described separately on pages 10 and 11 .

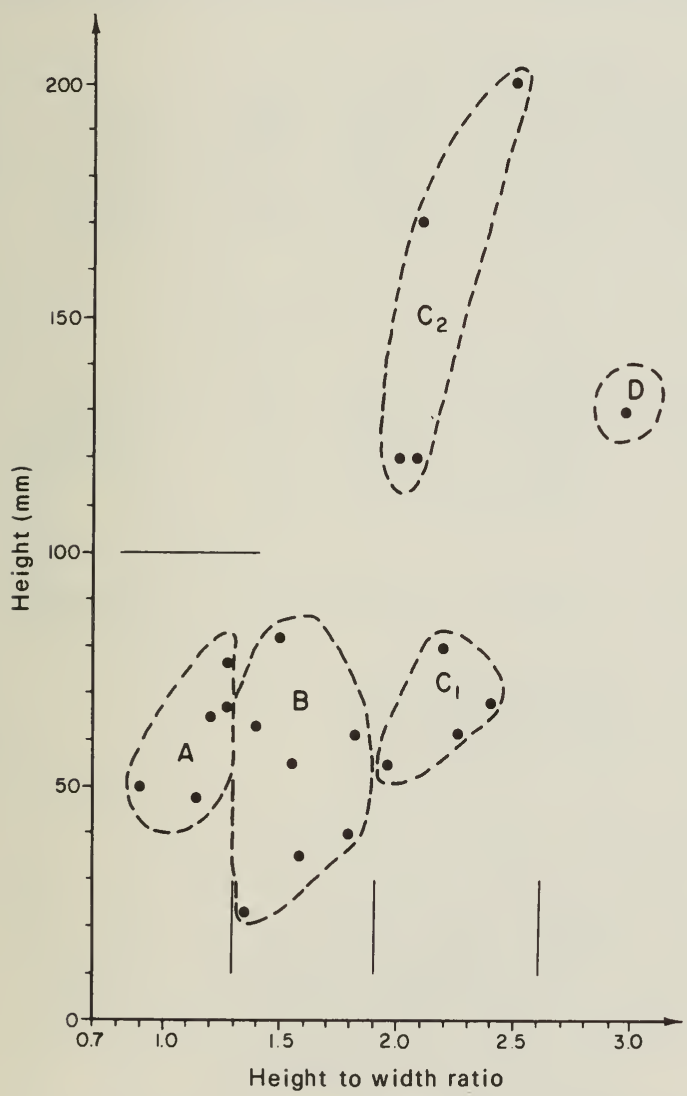

Text fig. 6 - Plot of height versus height to width ratio of leaf scars of Caulopteris specimens from Illinois.
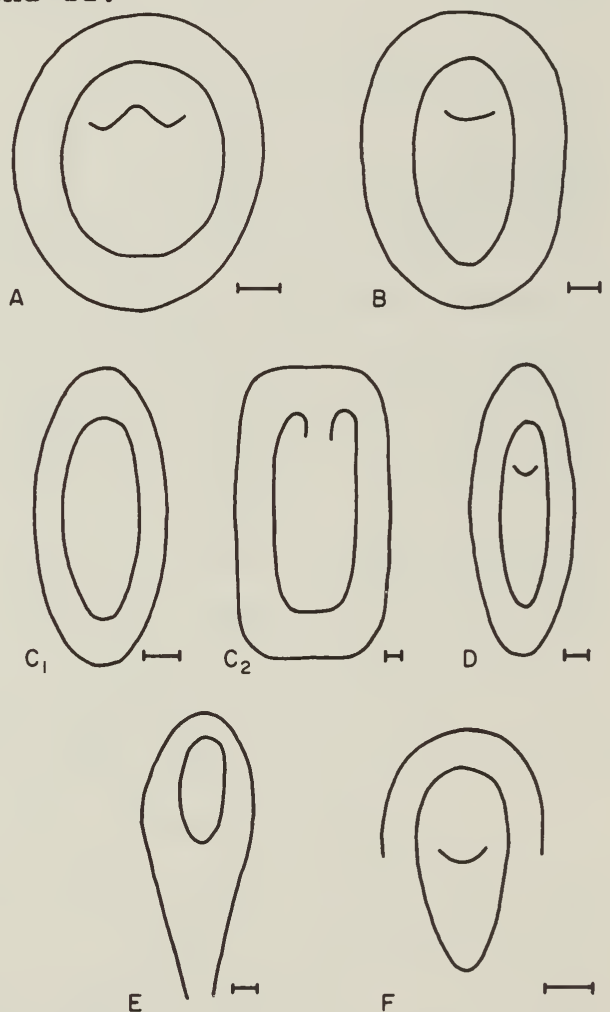

Text fig. 7 - Typical examples of the form-species of Caulopteris from Illinois. Scale bars represent $1 \mathrm{~cm}$. Letters A to D correspond to designation of species; E - Caulopteris/ Psaronius sp.; F - Caulopteris wortheni Lesquereux. 
TABLE 3 - MEASUREMENTS OF CAULOPTERIS SPECIMENS FROM ILLINOIS

\begin{tabular}{|c|c|c|c|c|c|c|c|}
\hline \multirow[b]{2}{*}{$\begin{array}{c}\text { Specimen } \\
\text { no. }\end{array}$} & \multicolumn{3}{|c|}{ Leaf scar } & \multicolumn{3}{|c|}{ Vascular trace } & \multirow[b]{2}{*}{ Location } \\
\hline & $\begin{array}{l}\text { Height } \\
\text { (mm) }\end{array}$ & $\begin{array}{c}\text { Width } \\
(\mathrm{mm})\end{array}$ & $\mathrm{H}: \mathrm{W}$ & $\begin{array}{l}\text { Height } \\
\text { (mm) }\end{array}$ & $\begin{array}{l}\text { Width } \\
(\mathrm{mm})\end{array}$ & $\mathrm{H}: \mathrm{W}$ & \\
\hline
\end{tabular}

Caulopteris sp. A

$\begin{array}{llllllll}\text { ISM 15088 } & 50 & 53 & 0.94 & 30 & 25 & 1.2 & \text { Braidwood } \\ \text { USNM } 41169 & 65 & 55 & 1.18 & 52 & 30 & 1.73 & \text { Braidwood } \\ \text { ISM } 15739 & 67 & 53 & 1.24 & 35 & 32 & 1.1 & \text { Braidwood } \\ \text { PP 13778 } & 48 & 42 & 1.14 & 32 & 24 & 1.33 & \text { Braidwood } \\ \text { ISM 15039 } & 77 & 62 & 1.24 & 42 & 28 & 1.5 & \text { Braidwood }\end{array}$

Caulopteris sp. B

$\begin{array}{lllllrll}\text { P 22035 } & 63 & 45 & 1.4 & 45 & 25 & 1.8 & ? \\ \text { PP 9996 } & 23 & 17 & 1.35 & 10 & 6 & 1.66 & \text { Braidwood? } \\ \text { PP 11830 } & 82 & 55 & 1.5 & 46 & 23 & 2.0 & \text { Braidwood } \\ \text { Harv. 7718 } & 55 & 35 & 1.56 & 35 & 20 & 1.75 & \text { Morris } \\ \text { ISGS PB-4457 } & 35 & 22 & 1.59 & 23 & 14 & 1.64 & \text { Herrin } \\ \text { ISGS PB-1152 } & 40 & 22 & 1.8 & 22 & 11 & 2.0 & \text { Westville } \\ \text { ISM 15330 } & 62 & 34 & 1.82 & 45 & 22 & 2.05 & \text { Braidwood }\end{array}$

Caulopteris sp. $\mathrm{C}_{1}$

$\begin{array}{llllllll}\text { ISM } 8666 & 55 & 28 & 1.96 & 45 & 17 & 2.65 & \text { Peoria } \\ \text { USNM 7125 } & 68 & 28 & 2.4 & 37 & 18 & 2.05 & \text { Peoria } \\ \text { USNM 7125 } & 62 & 30 & 2.26 & 38 & 20 & 1.9 & \text { Peoria } \\ \text { ISGS PB-1869 } & 85 & 38 & 2.2 & 51 & 18 & 2.83 & \text { Herrin }\end{array}$

Caulopteris sp. $\mathrm{C}_{2}$

\begin{tabular}{|c|c|c|c|c|c|c|c|}
\hline $\begin{array}{l}\text { PP } 3542 \\
\text { Langford, } 1958\end{array}$ & 120 & 60 & 2.0 & 52 & 22 & 2.35 & Braidwood \\
\hline Fig. 237 & (120) & (58) & 2.07 & $(82)$ & (31) & 2.6 & Braidwood \\
\hline Fig. 238 & 170 & 80 & 2.1 & 105 & 40 & 2.6 & Braidwood \\
\hline ISM 15803 & 200 & 80 & 2.5 & 130 & 52 & 2.5 & Braidwood \\
\hline
\end{tabular}

Caulopteris sp. D

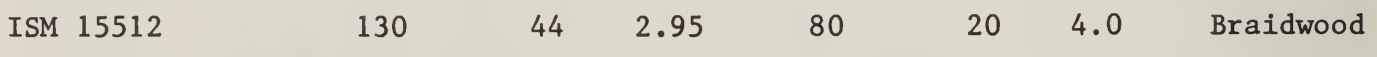

Caulopteris wortheni Lesquereux, 1866

Text fig. 7, F; pl. 3, fig. 2

The scar is narrow toward one end, and the vascular bundle is not completely visible. Thus the proper orientation is uncertain. Because there is an indented groove in the stem, starting at the open end of the scar (p1.3, fig. 2), it would appear that the open end was toward the top. However, if we interpret the internal trace as similar to the traces seen in Caulopteris species B and D (text fig. 7), the wider side would be toward the top. The latter interpretation was used for text figure $7, \mathrm{~F}$.

The specimen was found near Carmi in White County, Illinois, and is probably from the Bond or Mattoon Formation. Only the holotype of this species (ISM 1747) is known. It was redescribed and discussed by Janssen (1940). 
Caulopteris/Psaronius sp.

Text fig. 7, E; p1. 2, figs. 2-4; p1. 3, fig. 1

Three specimens of Caulopteris (Field Museum PP 11797, PP 11798, PP 17785) show traces of the vascular bundle in the stem. The stems are preserved as ironstone casts found in the Francis Creek Shale near Wilmington.

In the specimens three or four circles of vascular bundles are present. They are always somewhat removed from their original position, and the stems are in some places incomplete at the margin. Sections are shown in text figure 8 .

In specimens with this type of scar, the scars are far apart. From the outside, the leaf scars are quite different in appearance from those described in Caulopteris sp. A to D. In Caulopteris/Psaronius sp. the leaf scars are elongate and open on one end. This narrow, open end is probably the lower end of the scar. The orientation is best derived from examination of specimen PP 11797 (p1. 3, fig. 1), in which the upper margin of the leaf scar comes out of the stem.

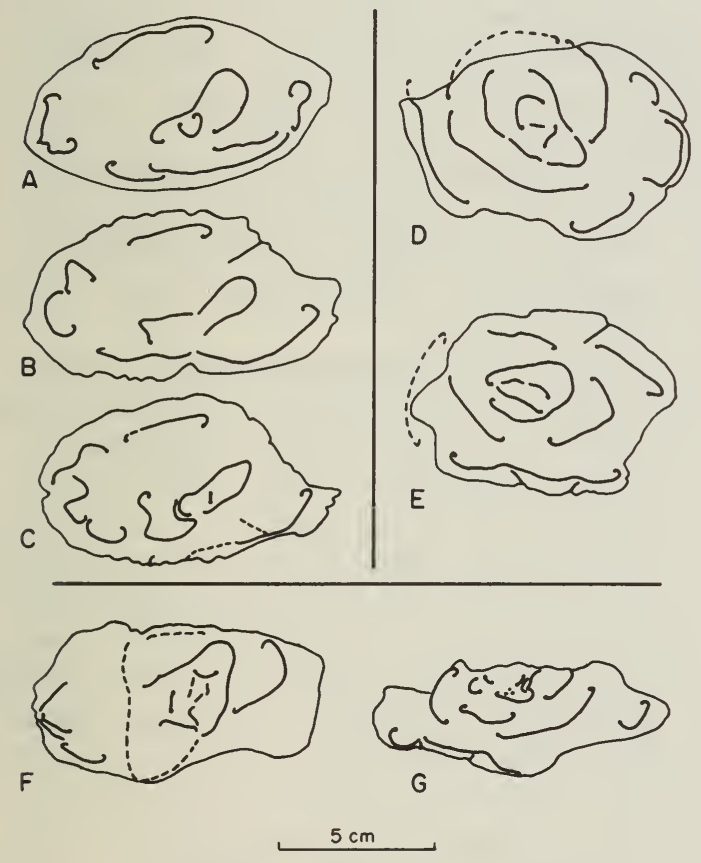

Text fig. 8 - Cross sections through specimens of Caulopteris/Psaronius sp. from the Francis Creek Shale of northern Illinois. A-C, specimen PP 17785, sections about $25 \mathrm{~mm}$ apart; D-E, specimen PP 11797 , sections about $85 \mathrm{~mm}$ apart; F-G, specimen PP 11798, sections about $230 \mathrm{~mm}$ apart.

\section{Specimens To Be Excluded from Caulopteris}

Several specimens identified as caulopteris should be transferred to other genera: "Caulopteris" radicans (Lesquereux, 1866) Janssen, 1940, is a decorticated lycopod stem. "Caulopteris" acantophora Lesquereux, 1870, is a mass of hairy axes or roots. "Caulopteris" langfordi Janssen, 1940, is a Lepidophloios as recognized by Langford (1958). The specimens figured by Langford (1963, p. 175179) as Caulopteris are actually root mantles of tree ferns (fig. $757 \mathrm{a}$ and b), a problematicum (figs. 758-760), and decorticated lycopod stems (figs. 761-765).

\section{DISCUSSION}

The characteristics used in classifying stems of Paleozoic tree ferns are: 1) shape of vascular bundle and 2) the presence of two rows or more than two rows of scars in the mature stem. On the basis of these characteristics, 
four stem genera can be recognized: Caulopteris, Megaphyton, Hagiophyton, and Artisophyton. The stem genera are shown diagrammatically in text figure 9.

Megaphyton has often been defined only by the distichous position of the leaf scars without regard to the form of the vascular bundle. Thus specimens called Megaphyton often included species with horseshoe-shaped traces as well as those with closed traces having an indentation as shown in text figure 4. However, differences in configuration of traces are much more meaningful for a systematic subdivision than is the distichous arrangement of the scars. Therefore, the genus Megaphyton must be divided. Artis (1825) described Megaphyton as having "cicatrices near together, horseshoe-shaped with the points upwards" (explanation of place 20). The plate itself, however, does not show this feature clearly. Similar circumstances surround the first description of $Z$ ippea by Corda (1845). Even though the figure of the type species of $Z$ ippea disticha does not show any trace of a vascular bundle, Corda (1845) stated that he had other specimens which show a

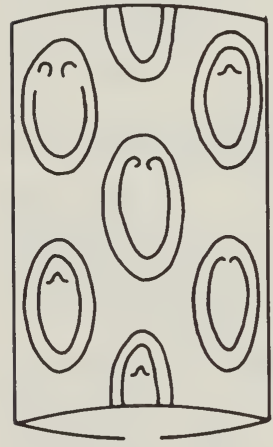

A Caulopteris

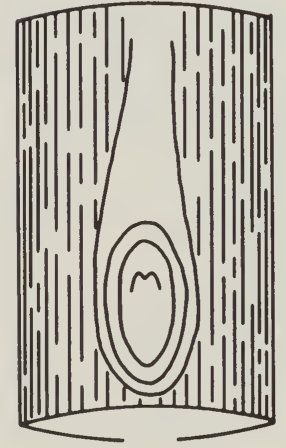

C Hagiophyton

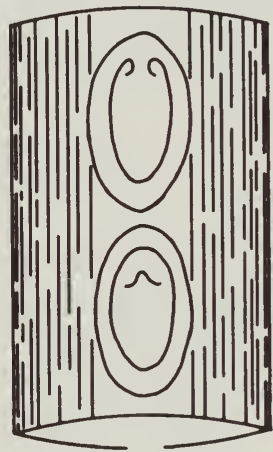

B Megaphyton

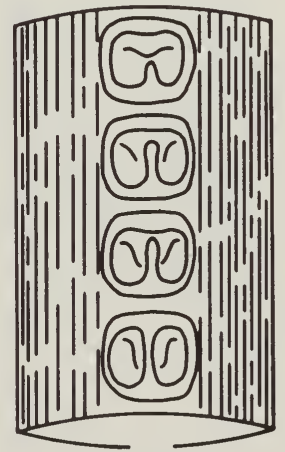

D Artisophyton

Text fig. 9 - Diagrammatic drawings of the compression-impression genera of stems of tree ferns of Pennsylvanian age.

horseshoe-shaped trace, and he illustrated the trace with a drawing. Corda's specimen is interesting because some internal features can be seen. The stems are preserved in sandstone and are still round. The outline of the vascular bundle is visible as a band of carbon in the cross section of the stem. The vascular bundles are band shaped like those in Psaronius.

For the stems which have in their leaf scars a configuration of the vascular bundle as shown in text figure 4, the new name Artisophyton is used.

Hagiophyton is very similar to Megaphyton and might well be a synonym of it. The only difference is that in Hagiophyton, as described by Corsin (1948), a sclerenchymous band surrounds the vascular trace.

\section{Natural Systematics}

Internal structures have been found in connection with specimens of Caulopteris and Megaphyton. Therefore it is established and well known that these two genera belong to the Psaronius group and can be classified as Marattiaceae. 
There is, to my knowledge, no structurally preserved material that can be attributed to Artisophyton. Information on the systematic position of Artisophyton is therefore restricted to circumstantial evidence.

Corsin (1948) made the point that Artisophyton (he called it Megaphyton) probably bore foliage of the Pecopteris plumosa-P. pennaeformis group, which bears Senftenbergia sporangia. His reasoning was as follows. The vascular trace in Artisophyton divides into two independent traces (text fig. 4). This division most probably indicates a forking of the rachis of the frond relatively close to the stem. This feature occurs in several groups of Pennsylvanian plants, including some pteridosperms, some coenopterids, and the Pecopteris plumosa-P. pennaeformis group. The pteridosperms with forked fronds and the coenopterids with forked fronds have totally different types of vascular bundles from those of Artisophyton. Thus the only possibility left among the known groups with forked fronds is the Pecopteris plumosa-P. pennaeformis group. Furthermore, $P$. plumosa and the related species that have very large fronds occur in the same beds as Artisophyton, which had leaf scars up to $12 \mathrm{~cm}$ in diameter. This association of $P$. plumosa and related species with Artisophyton occurs in northern France as well as in Illinois. Thus there is at least a possibility that Artisophyton stems bore Pecopteris plumosa foliage with Senftenbergia sporangia.

Senftenbergia has been classified with the Schizeaceae on the basis of the structure of the sporangia. Jennings and Eggert (1972). investigated the anatomy of Senftenbergia and its foliage and considered the genus a coenopterid fern. It could follow that there were coenopterid tree ferns in Pennsylvanian time.

\section{Differences Between Species}

The characteristic widely used in differentiating the 100 species of Caulopteris and the 43 species of Megaphyton and Artisophyton (number of species from the "Fossilium Catalogus," Jongmans and Dijkstra, $1959,1961)$ was the small variation in the shapes of the vascular bundle. Renault and Zeiller, 1888 (seen in Andrews and Doubinger, 1970), however, described a specimen of Caulopteris varians that showed different configurations of the vascular bundle on one stem. Recently Stidd (1971) demonstrated that different shapes of the leaf traces in Psaronius occur in the basal part of the same rachis (text fig. 10). In earlier publications, the specimens represented in text figure 10, A to F, would have been treated as six species. Now that these different vascular configurations have been recognized as developmental stages, it is clear that they do not necessarily

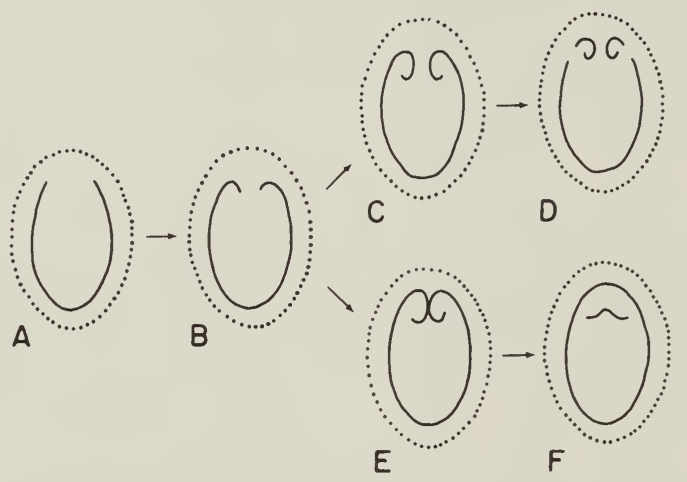

Text fig. 10 - Configuration of vascular bundle in leaf scars of Caulopteris and Megaphyton and the supposed deve1opmental sequence in the basal part of a rachis. A is closest to the point of origin. Dotted line is outline of leaf scar. Sequence A to D is stewartiopteroid and sequence A, B, E, F is stipitopteroid. 
indicate systematic differences. The development shown in text figure 10, C to D, seems to indicate a simpler pattern of the pinna trace development than that shown in text figure 10, E to F. From coal balls two sequences of pinna trace formation have been described (stipitopteris and stewartiopteris). As stipitopteris and stewartiopteris have been shown by Stidd (1971) to occur within the same rachis, even this distinction does not indicate a systematic difference.

Size, shape, and relative positions of leaf scars are another set of supposedly specific characteristics. However, in living species of tree ferns, extreme variations of these characteristics have been observed (see text fig. 11). Most living tree ferns belong to the Cyatheaceae, which are taxonomically and phylogenetically quite distant from the Marattiaceae. However, the two groups are structurally quite similar, and therefore comparisons of morphological characteristics are valid. Differences in size and shape of leaf scars can occur in living Cyatheaceae on different stems of the same species or even on different parts of the same stem owing to ecological changes (oral communication, Professor Rolla Tryon and Dr. Alice F. Tryon, 1973). In the Pennsylvanian, arrangements of leaf scars in Caulopteris vary from densely packed to widely separated (text fig. 12). If we assume that the fossil forms grew
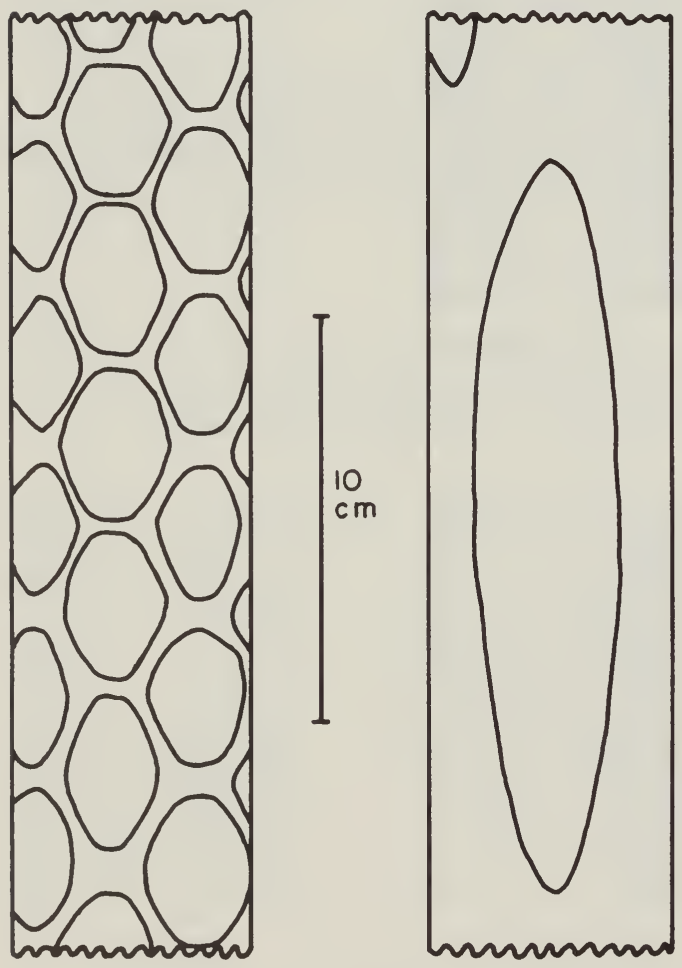

Text fig. 11 - Trunks of Cyathea arborea showing extreme variety of leaf scar size and arrangement within one species of living tree ferns (after Maxon, 1912, p1. 3).
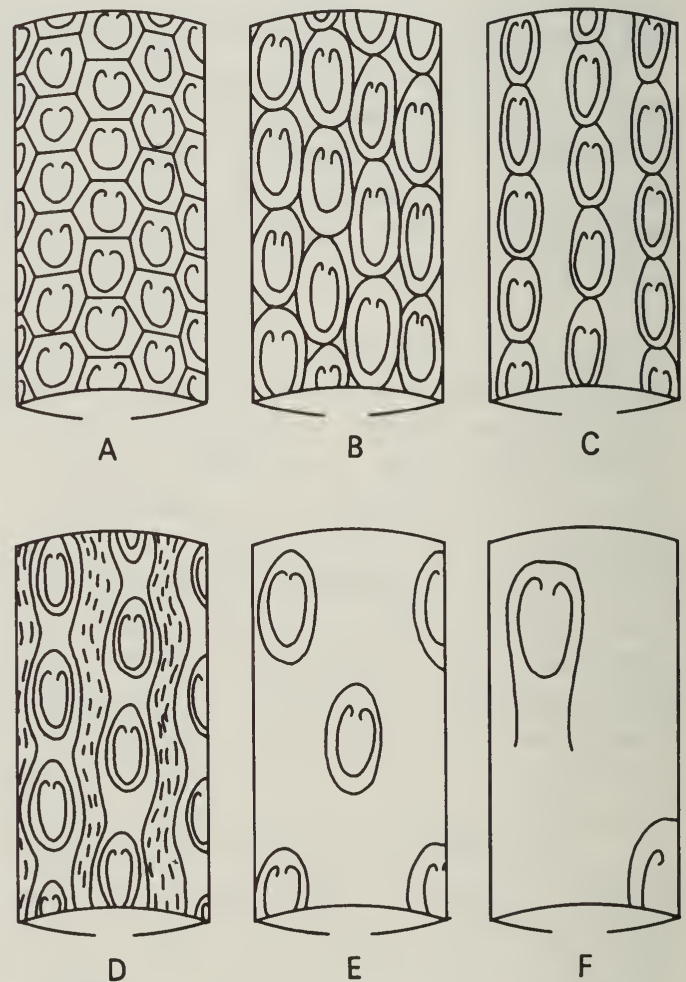

Text fig. 12 - Some types of arrangement of leaf scars occurring in Caulopteris (A after C. saportae from Hirmer, 1927; $B$ after $C$. varians from Andrews and Doubinger, 1970; C to F possible stages). 
the way that the living ones grow, all of these patterns could occur in one species.

Apparently, natural species of tree ferns cannot be distinguished by leaf scar patterns. However, form-species can be useful and should be clearly defined. The limits for defining a form-species should be large enough to include a wide variation of characteristics but small enough to show any trends of change that might be present. The following characteristics are suggested for use and are used in this paper:

1) the height to width ratio of the leaf scar; 2) the size (height) of the leaf scar; and, to a certain degree, 3) the shape of the leaf scar.

The different configurations of the vascular bundle found in leaf scars of Artisophyton can be interpreted as a developmental sequence in one species (text fig. 4). The specimen shown on plate 4 demonstrates that different configurations can and did occur on one stem. The suggestion that different configurations occur in the same species was first made by Corsin (1948).

The species differentiation in Artisophyton must thus be based on artificial characteristics (size and height to width ratio) the same as those used in the other stem genera. The differentiation is somewhat simpler in Artisophyton because there are only two types of leaf scars, those with a height to width ratio greater than 1 (height $>$ width) and those with a ratio of 1 and less than 1 (height < width).

\section{Orientation of Leaf Scars}

Most of the leaf scars of Caulopteris, Megaphyton, and Artisophyton are found as fragments of stems and thus do not alluw any conclusions about the proper orientation (adaxial side versus abaxial side). Therefore, figures in the literature are oriented either way without regard to the natural orientation on the living stem.

A horseshoe-shaped vascular bundle occurs in Caulopteris, Megaphyton, and Hagiophyton. If we assume that these three genera were similar in organization to Psaronius and the living Marattiaceae, the proper orientation is defined. The horseshoe is adaxially (at the top) open; and in the closed stage (see text fig. 10, E and F), the inner trace is in the upper portion of the outer trace. Unless the contrary is proven, all leaf scars of these three genera should be shown in that orientation.

The orientation of the leaf scars of Artisophyton is more problematical because no comparable living or petrified plant is known. The original orientation of the stem cannot be determined from single leaf scars that occur in ironstone nodules. There is, however, a specimen (ISGS PB-1298) in which both sides of an Artisophyton stem are preserved (p1. 4). A reconstruction is shown in text figure 13. The row of scars to the left represents the outside of the stem facing the viewer. On the right we look into the stem, the internal tissue being gone and replaced by a thin shale layer. Thus the row of leaf scars on the right is the compression of the outer layer of the stem as it appears from the inside. This information alone does not yet tell us the natural position of the stem. Some data derived from the vascular bundle must be added. The preserved surfaces not only show the vascular bundle 


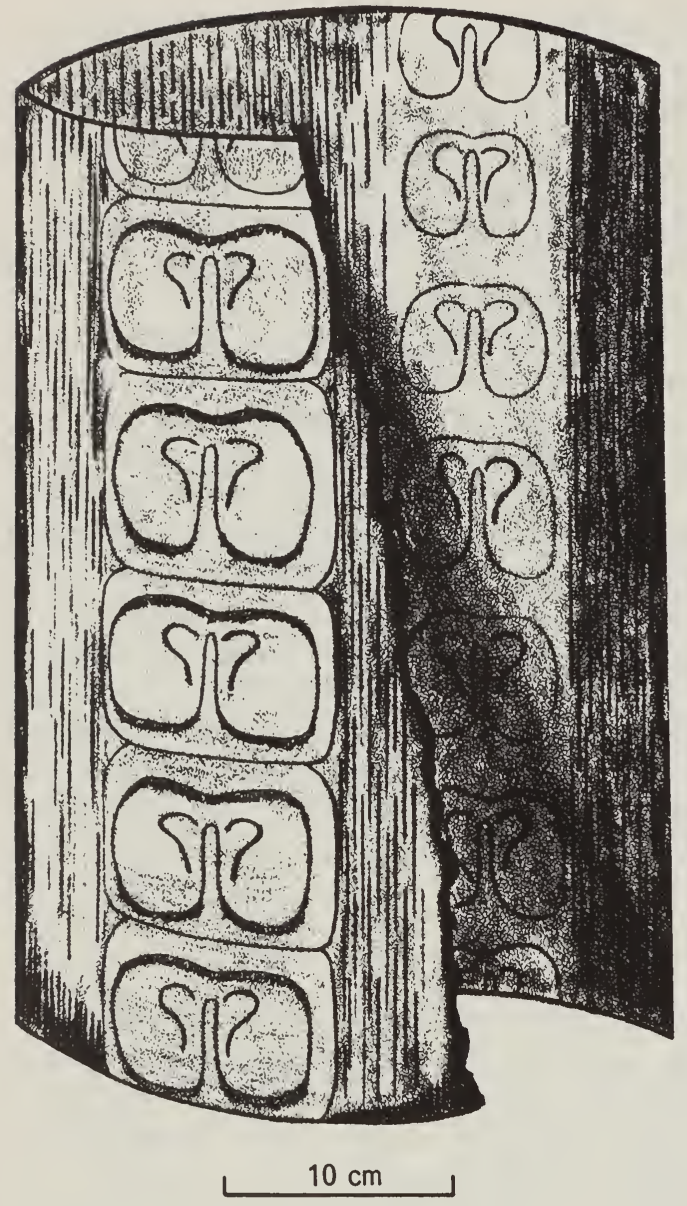

in cross section but show a short part of it as an inclined ribbon. We know that the vascular bundle originally grew upward and outward. If we combine this information with the knowledge of the position of the outside of the stem in the specimen, we can determine the natural position of the stem fragment. It becomes clear from this specimen (ISGS PB-1298) that the indentation of the outer vascular bundle is in the lower (abaxial) side and that the inner trace is in the upper part of the scar.

Text fig. 13 - Reconstruction of part of the stem of Artisophyton mclayi after specimen ISGS PB-1298. This reconstruction demonstrates the natural orientation of leaf scars in Artisophyton.

\section{REFERENCES}

Andrews, H. N., and Jeanne Doubinger, 1970, Genre Caulopteris Lindley et Hutton, 1832, p. 192-200, and Genre Megaphyton Artis, 1825, p. 200-201, in Boureau, E. (ed.), 1970, Traité de Paléobotanique, v. IV, part 1, Filicophyta. Paris: Masson et Cie., 519 p., 378 figs.

Artis, E. T., 1825, Antediluvian phytology, illustrated by a collection of the fossil remains of plants, peculiar to the coal formations of Great Britain. London: 13 p., 24 pls. with 24 p. of explanation.

Corda, A. J., 1845, Flora Protogaea - Beiträge zur Flora der Vorwelt. Berlin: Calvary und Co., 128 p., 60 pls.

Corsin, Paul, 1948, Reconstitutions de Pécoptéridées: genres Caulopteris Lindley and Hutton, Megaphyton Artis et Hagiophyton nov. gen.: Annales du Société Géologique du Nord, v. 67 (1947), p. 6-25, 4 figs., 4 pls. 
Crookal1, R., 1955, Fossil plants of the Carboniferous rocks of Great Britain: Memoir, Geological Survey of Great Britain, Palaeontology, v. 4, pt. 1, 84 p., 32 figs., 24 pls.

Darrah, W. C., (1969) 1970, A critical review of the Upper Pennsylvanian floras of eastern United States with notes on the Mazon Creek flora of Illinois: Privately published, Gettysburg, Pa., 220 p., $80 \mathrm{pls}$.

Gillette, N. J., 1937, Morphology of some American species of Psaronius: Botanical Gazette, v. 99, p. 80-102, 20 figs.

Grand'Eury, F. C., 1890, Géologie et paléontologie du bassin houiller du Gard. St. Étienne: Impr. Théolier \& Cie., 354 p., 22 pls.

Hirmer, Max, 1927, Handbuch der Paläobotanik. Band I: Thallophyta, Bryophyta, Pteridophyta. München und Berlin: R. Oldenbourg, 708 p., 817 figs.

Janssen, R. E., 1940, Some fossil plant types of Illinois: Illinois State Museum Scientific Papers, v. 1, 124 p., 29 pls.

Janssen, R. E., 1957 (2nd ed.), Leaves and stems from fossil forests: Illinois State Museum, Popular Science Series, v. 1, 190 p., 165 figs.

Jennings, J. R., and D. A. Eggert, 19\%2, Senftenbergia is not a Schizaeaceous fern: American Journal of Botany, v. 59, no. 6, part 2, p. 676 (abstr.).

Jongmans, W. J., and S. J. Dijkstra, 1959, Filicales, Pteridospermae, Cycadales, 9: Fossilium Catalogus, II: Plantae, Pars 36, p. 601-750.

Jongmans, W. J., and S. J. Dijkstra, 1961, Filicales, Pteridospermae, Cycadales, 18: Fossilium Catalogus, II: Plantae, Pars 45, p. 1597-1686.

Langford, George, 1958, The Wilmington coal flora from a Pennsylvanian deposit in Will County, Illinois. Downers Grove, Illinois: Esconi Associates, 360 p., 674 figs.

Langford, George, 1963, The Wilmington coal fauna and additions to the Wilmington coal flora from a Pennsylvanian deposit in Will County, Illinois. Downers Grove, Illinois: Esconi Associates, 280 p., 471 figs.

Lesquereux, Leo, 1866, Report on the fossil plants of Illinois, in Worthen, A. H., 1866, Palaeontology: Geological Survey of Illinois, v. 2, p. 425-467, 17 pls.

Lesquereux, Leo, 1870, Report on the fossil plants of Illinois, in Worthen, A. H., 1870, Geology and palaeontology: Geological Survey of Illinois, v. 4, p. 375-508, 31 pls. 
Lesquereux, Leo, 1879-1884, Description of the coal flora of the Carboniferous formation in Pennsylvania and throughout the United States: Second Geological Survey of Pennsylvania, Report of Progress P: Atlas, 87 pls., 1879; v. 1 and 2, p. 1-694, 1880; v. 3, p. 695-977, p1s. 88-111, 1884 .

Lindley, John, and William Hutton, 1831-33, Fossil flora of Great Britain or figures and descriptions of the vegetable remains found in a fossil state in this country. London: James Ridgway, v. 1, $223 \mathrm{p} ., 79 \mathrm{p} 1 \mathrm{~s}$.

Lindley, John, and William Hutton, 1833-35, Fossil flora of Great Britain or figures and descriptions of the vegetable remains found in a fossil state in this country. London: James Ridgway, v. 2, $208+28 \mathrm{p} ., 76 \mathrm{pls}$.

Maxon, W. R., 1912, The tree ferns of North America: Annual Report, Smithsonian Institution, 1911, p. 463-491, 15 pls.

Morgan, E. J., 1959, The morphology and anatomy of American species of the genus Psaronius: Illinois Biological Monograph 27, 108 p., 82 figs.

Noé, A. C., 1925, Pennsylvanian flora of northern Illinois: Illinois State Geological Survey Bulletin 52, 113 p., 45 pls.

Stidd, B. N., 1971, Morphology and anatomy of the frond of Psaronius: Palaeontographica B, v. 134, p. 87-123, 10 figs., 3 tables, $16 \mathrm{p} 1 \mathrm{~s}$.

Weiss, Ernst, 1860, Ueber ein Megaphytum der Steinkohlen-Formation von Saarbrücken: Zeitschrift der deutschen geologischen Gese11schaft, v. 12, p. 509-512. 
PLATES

AND

\section{EXPLANATIONS}




\title{
PLATE 1
}

\author{
Figure \\ 1 Caulopteris sp. A, ISM 15739, scale 1:1, \\ Francis Creek Shale, Braidwood, \\ Will County, Illinois. \\ 2 Caulopteris sp. A, PP 13778, scale 1:1, \\ Francis Creek Shale, Braidwood. \\ 3 Caulopteris sp. B, PP 11830 , scale $1: 1$, \\ Francis Creek Shale, Braidwood. \\ 4 Caulopteris sp. $\mathrm{C}_{2}$, PP 3542 , scale $1: 1$, \\ Francis Creek Shale, Braidwood. \\ 5 Caulopteris sp. $\mathrm{C}_{2}$, PP 727 , scale $1: 1$, \\ Francis Creek Shale, Braidwood.
}



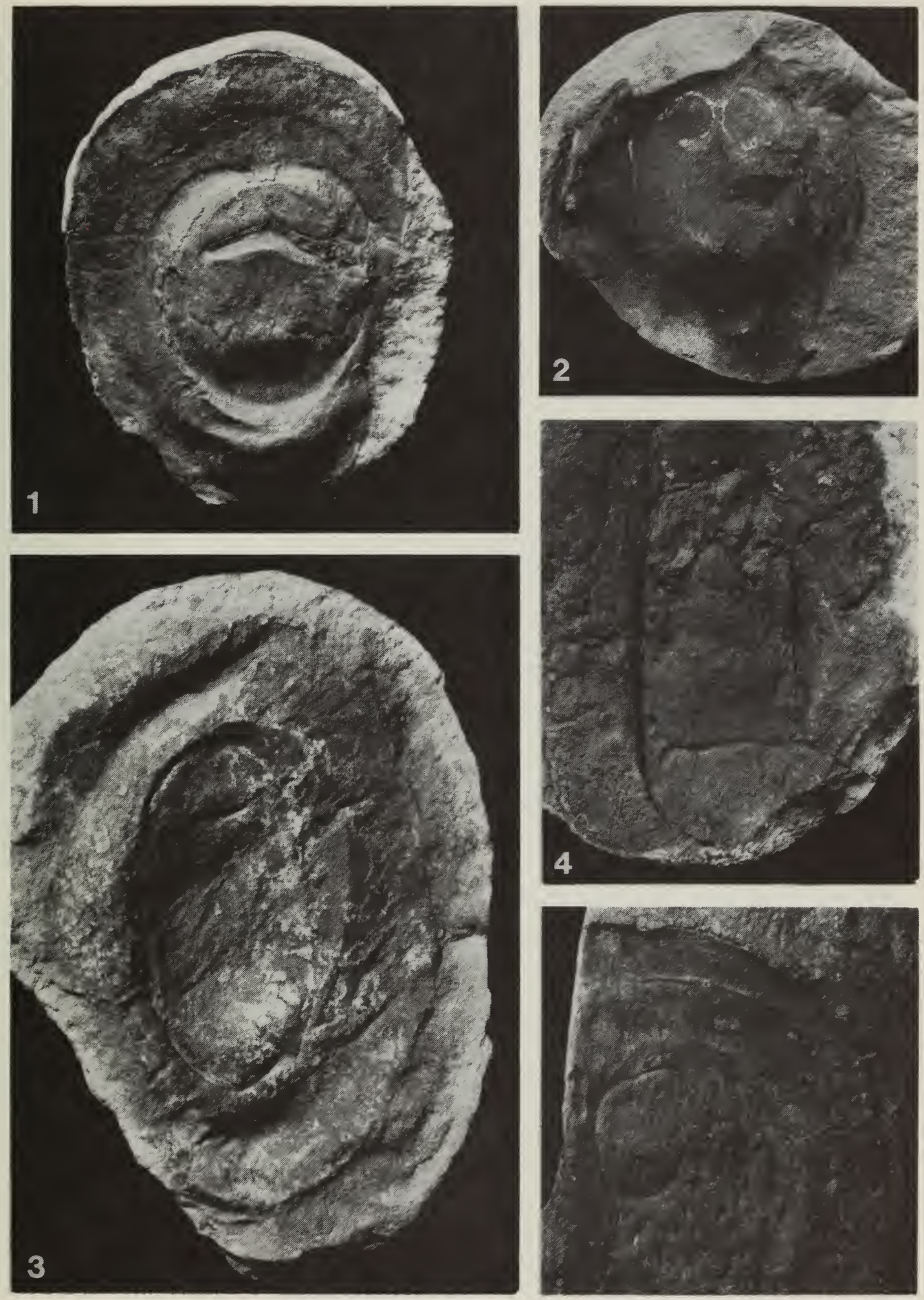
PLATE 2

Figure

1 Caulopteris sp. D, ISM 15512, scale 1:1.

2 Caulopteris/Psaronius sp., PP 11798, scale $1: 2$. With respect to the natural orientation, the stem is probably shown upside down in this figure.

3 Section through Caulopteris/Psaronius sp., PP 17785, scale $1: 1$, showing the calcite bands replacing the vascular bundles (section A, text fig. 8).

4 Section through Caulopteris/Psaronius sp., PP 17785, scale $1: 1$, showing outline of marginal vascular bundle (section C, text fig. 8). 

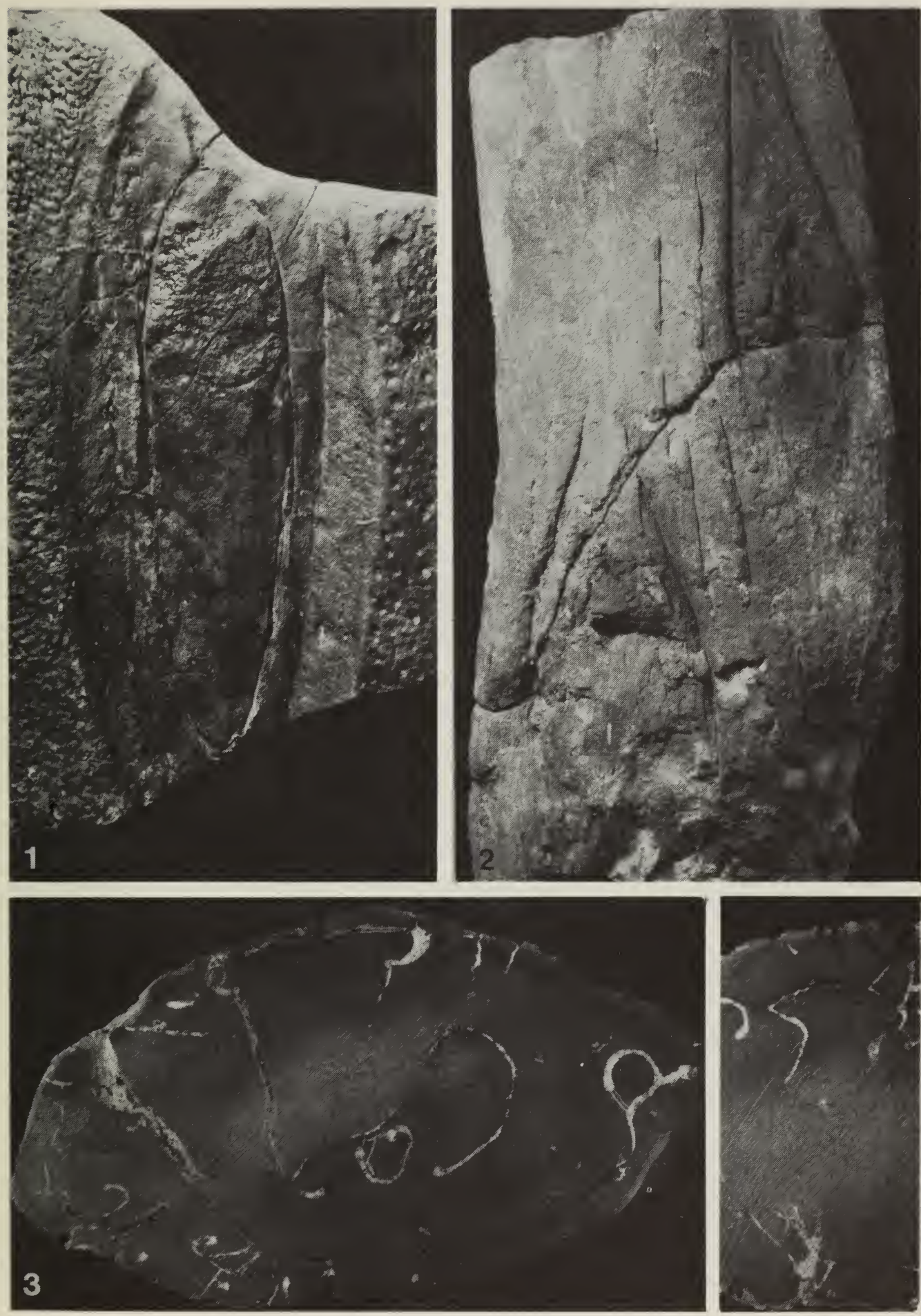


\section{PLATE 3}

Figure

1 Caulopteris/Psaronius sp., PP 11797, scale 1:1, Francis Creek Shale, near Braidwood, Will County, Illinois.

2 Caulopteris wortheni, ISM 1747 , scale 1:1, holotype, probably Bond or Mattoon Formation, near Carmi, White County, Illinois. 

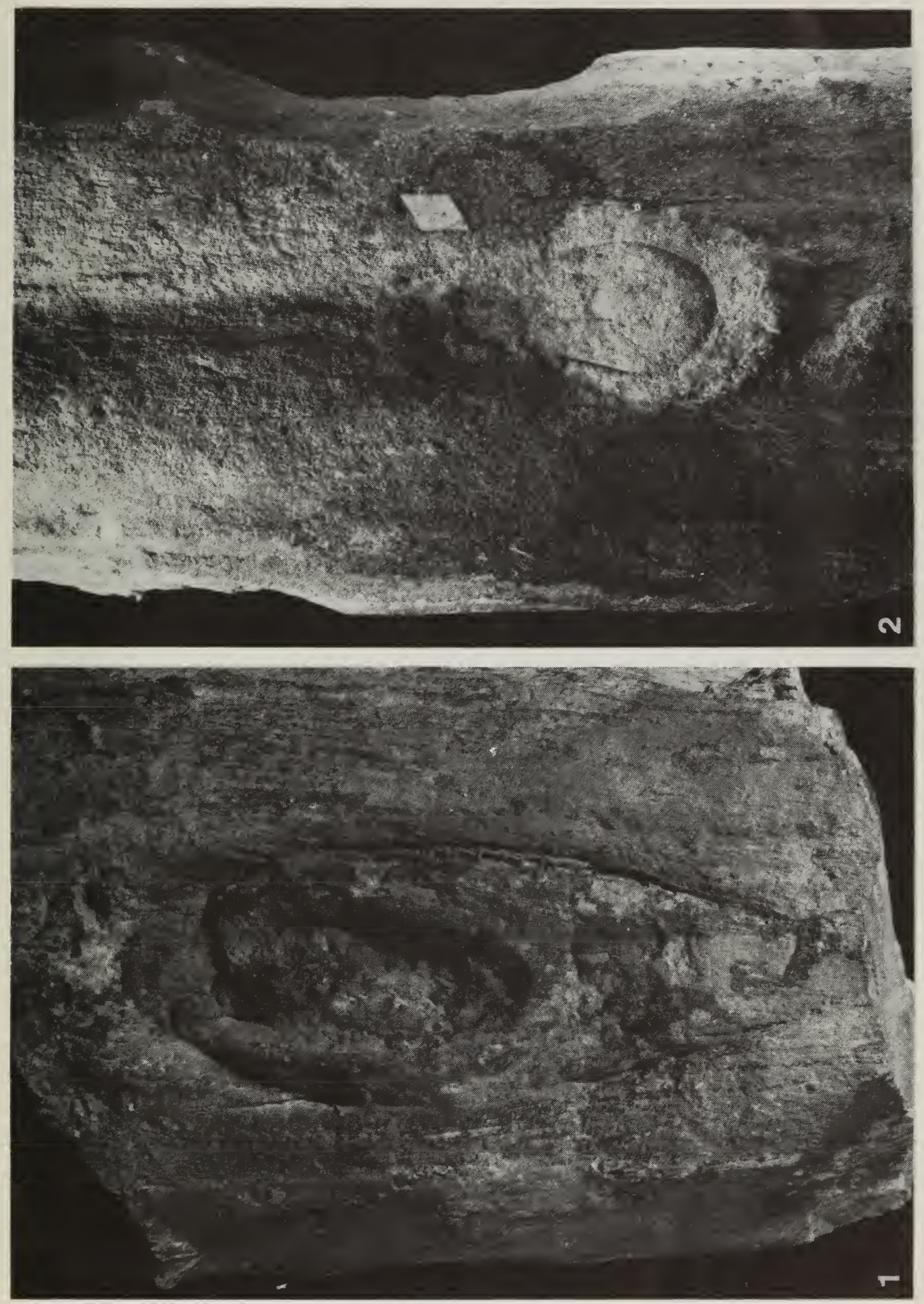


\section{PLATE 4}

\section{Artisophyton mclayi}

ISM 1298, scale $1: 2.5(1 \mathrm{~cm}=2.5 \mathrm{~cm})$, Energy Shale, 01d Ben No. 11 Mine, Christopher, Franklin County, Illinois. Both sides of one stem are preserved. See text figure 13 for reconstruction. 


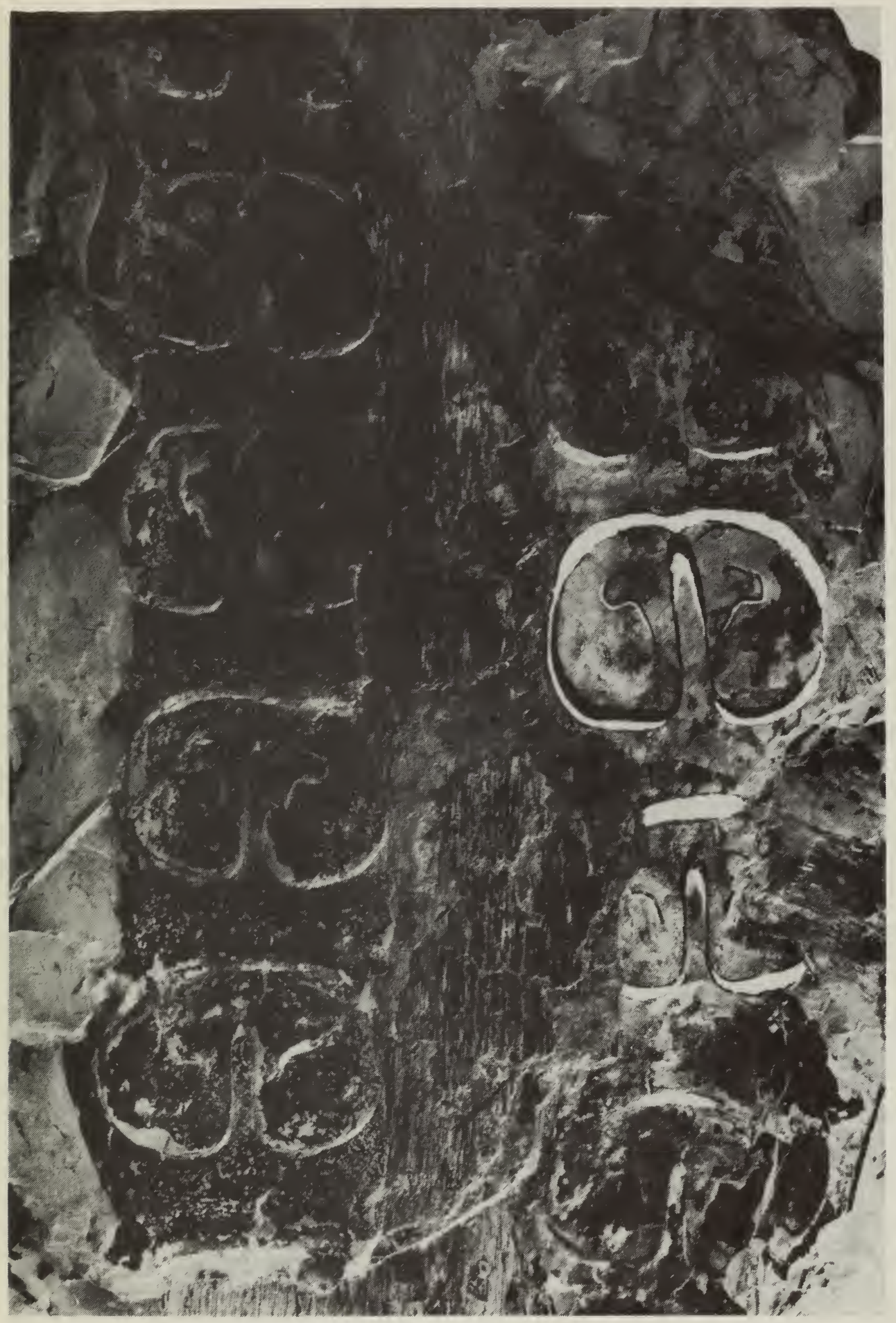




\section{PLATE 5}

\section{Figure \\ 1 Megaphyton protuberans, ISM 1632 , scale 1:1, Chesterian (probably lower part), Bay City, Pope County, Illinois.}

2 Artisophyton insignis, PP 2936, scale 1:1, Francis Creek Shale, Langford Collection. The two separated vascular traces are visible. 

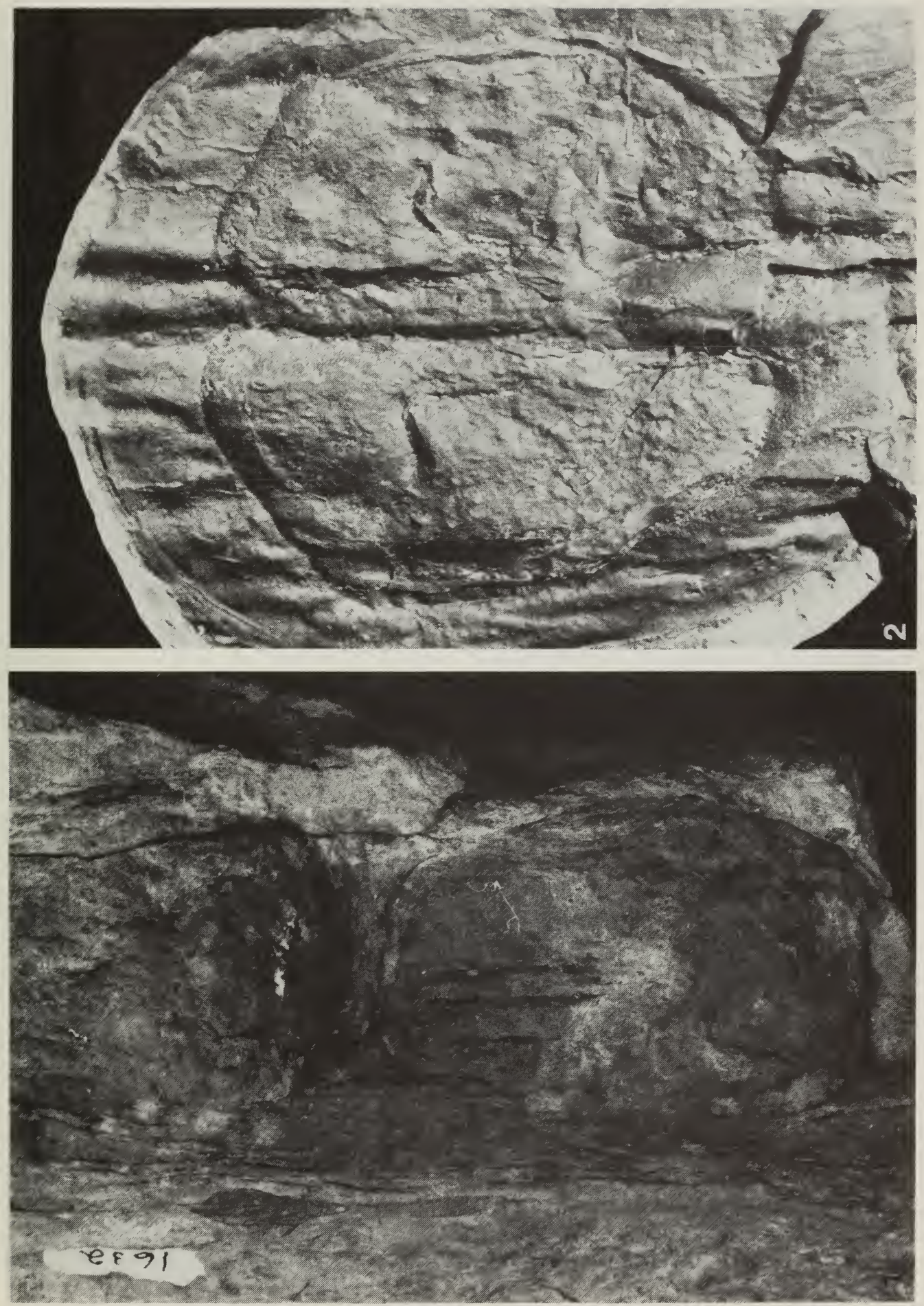


\section{PLATE 6}

\section{Figure}

1 Artisophyton malayi, ISM 1782, scale 1:1, Du Quoin, Perry County, Illinois.

2 Artisophyton insignis, ISGS PB-3299, scale 1:1, Energy Shale, 0ld Ben No. 11 Mine, Christopher, Franklin County, Illinois.

3 Artisophyton insignis, ISM 14555, scale 1:1, Francis Creek Shale, Langford Collection. 

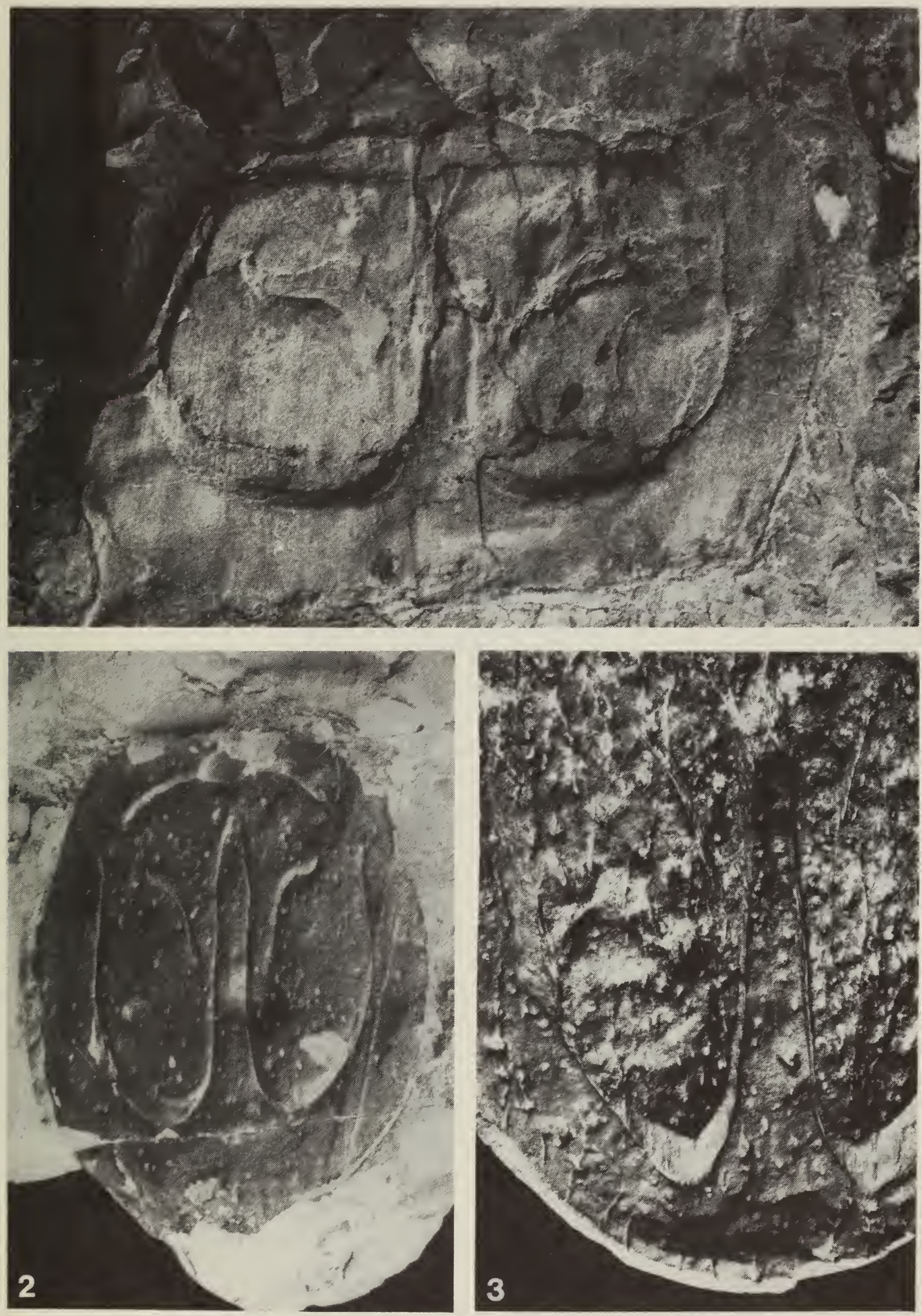
Illinois State Geological Survey Circular 492

31 p., 13 text figs., 3 tables, 6 plates, 2500 cop., 1976 Urbana, Illinois 61801

Printed by Authority of State of Illinois, Ch. 127, IRS, Par. 58.25. 

CIRCULAR 492

ILLINOIS STATE GEOLOGICAL SURVEY URBANA, IL 61801 